\title{
PENENTUAN DAERAH RAWAN KECELAKAAN DENGAN PENDEKATAN METODE JARINGAN SYARAF TIRUAN
}

\author{
Annur Ma'ruf ${ }^{* 1}$ \\ 1Dosen / Program Studi Teknik Sipil / Institut Teknologi Nasional Malang \\ Korespondensi: uphiks@gmail.com
}

\begin{abstract}
Technology improvement gives positive impacts on increasing transportation mode. But it has a negative impact such as traffic jam and increasing number in traffic accident, so road safety issues must be a common concern. One of the efforts to prevent tha accident is to identify accident-prone areas as a warning system for user. Eleven road sections in Malang District and supported data from Satkorlantas Polres Malang District is used as scope of discussion in this study. In this study, the factors that caused accidents such as road characteristic, geometric and environment condition is used for identifcation the accident-prone area. Based on the data, database mapping was done and the pattern of potential accident-prone areas was determined. It can be used for analysis and decision. Mapping and testing process uses a neural network approach because the accuracy of this method has been already proven in various applications. The results approach on prone area identification indicates a precision with a variance of $0.015 \%$ in compare with accident-based data analysis through the validation process. This result shows that neural network approach can be used to identify the accident-prone areas as one of the solution in accident prevention and efforts in road safety improvement.
\end{abstract}

Keywords: Accident-prone area, Highway, Neural network, Safety

\section{PENDAHULUAN}

Pertumbuhan penduduk pada suatu wilayah diiringi dengan perkembangan teknologi transportasi sebagai sarana penghubung antar wilayah. Mobilitas masyarakat menjadi semakin mudah sehingga kesejahteraan masyarakat meningkat. Namun terdapat sisi negatif akibat pertumbuhan transportasi, antara lain timbulnya kemacetan dan masalah kecelakaan lalu lintas [3].

Berdasarkan penelitian terdahulu, peningkatan jumlah kepemilikan kendaraan berkorelasi positif dengan meningkatnya jumlah angka kecelakaan. Hampir di semua negara didunia, kecelakaan di jalan raya masih menjadi penyebab kematian terbesar dengan menempati posisi ke sembilan. Hal ini juga terjadi di negara berkembang seperti Indonesia dimana kecelakaan lalu lintas merupakan penyebab kematian setelah penyakit jantung dan tuberkolusis. Kecenderungan kejadian kecelakaan lalu lintas di Indonesia semakin tahun semakin meningkat $[3,4]$.
Adanya tren peningkatan angka kecelakaan lalu lintas tidak luput dari berbagai faktor pemicu kejadian tersebut. Menurut Haddon's matrix, penyebab utama dari kecelakaan adalah faktor manusia, kendaraan dan lingkungan, dimana faktor-faktor tersebut dapat dikaji secara lebih jauh lagi tergantung pada tahapan kejadian kecelakaan yaitu pra kecelakaan, saat kejadian kecelakaan dan pasca kecelakaan [4].

Sementara itu, Kabupaten Malang sebagai daerah penyangga kota metropolitan Surabaya dengan letak yang dikelilingi oleh kota-kota strategis disekitarnya seperti kota Malang, memberi dampak pada wilayah ini akan adanya mobilitas yang tinggi dari waktu ke waktu, namun dengan ketersediaan jalan yang dimiliki yaitu mencapai $1.899,32 \mathrm{~km}$ terdiri dari $115,63 \mathrm{~km}$ merupakan jalan nasional, $114,93 \mathrm{~km}$ jalan propinsi dan $1.678,76 \mathrm{~km}$, belum mampu memenuhi pergerakan masyarakat untuk menjalankan kegiatan roda perekonomian daerah. Dukungan sarana dan 
prasarana jalan cenderung bersifat stagnan disertai moda transportasi publik yang tersedia masih jauh dari harapan masyarakat. Pertumbuhan kendaraan yang tidak seimbang dengan peningkatan panjang jalan baru, mengakibatkan timbulnya permasalahan lalu lintas seperti kemacetan dan kecelakaan lalu lintas [6, 8]. Gambar peta jaringan jalan di wilayah Kabupaten Malang seperti tercantum pada Gambar 1.

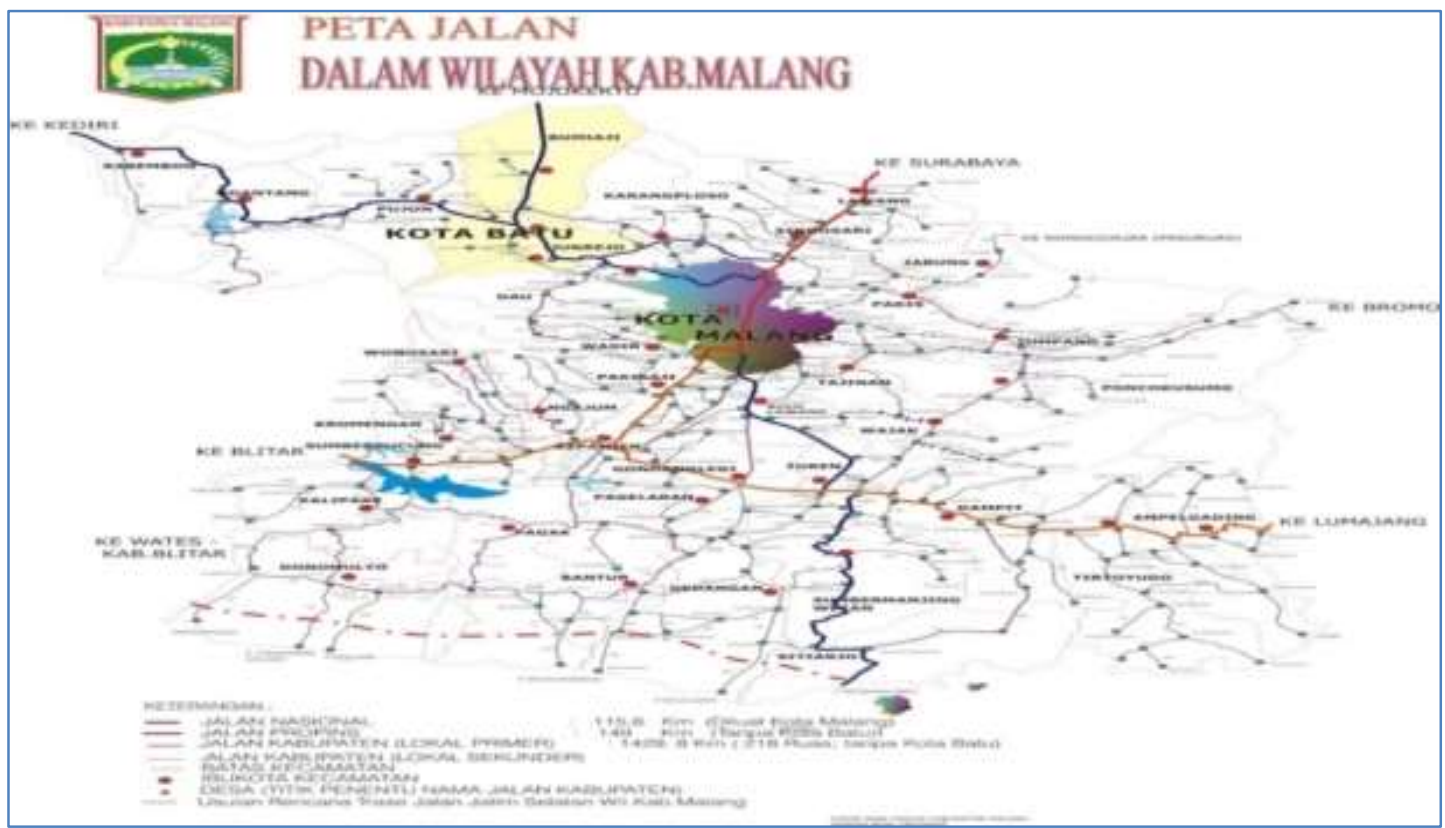

Gambar 1. Peta jaringan jalan

Pada periode tahun 2010-2015, data dari Satlantas Polres Kabupaten Malang menyebutkan bahwa terdapat 764 kejadian kecelakaan dengan korban meninggal dunia sejumlah 213 orang, 16 orang dengan luka berat, 978 orang mengalami luka ringan serta kerugian materi sekitar Rp 400.000.000,- [7]. Data ini menunjukkan bahwa angka kecelakaan lalu lintas yang terjadi di Wilayah Kabupaten Malang harus menjadi perhatian bersama dan memerlukan upaya pencegahan untuk mengurangi kejadian kecelakaan di jalan raya.

Salah satu upaya pencegahan kecelakaan lalu lintas adalah dengan melakukan analisis terhadap daerah rawan kecelakaan, karena hasil analisis ini dapat digunakan sebagai peringatan atau tanda bagi pengendara ketika melewati area tersebut untuk lebih berhati-hati, dengan harapan dapat menekan angka kecelakaan [7, 8].

Analisis terhadap suatu wilayah dalam kawasan jalan raya yang memiliki potensi sebagai daerah rawan kecelakaan umumnya menggunakan data kecelakaan di wilayah yang ditinjau, namun tanpa data kecelakaan pun masih dapat dilakukan analisis terhadap daerah rawan kecelakaan dengan mengidentifikasi seluruh data penyebab kecelakaan seperti faktor kondisi dan karakteristik lintasan jalan raya. Hal ini merupakan salah satu tindakan dan prosedur dalam teknik audit keselamatan jalan sebagai upaya dalam meningkatkan keselamatan pengguna jalan raya $[1,5,9]$.

Berdasarkan pada data-data faktorfaktor yang berkaitan dengan kecelakaan lalu lintas di jalan raya, maka terdapat peluang adanya suatu kajian tentang keselamatan jalan raya, dengan menyusun suatu pola untuk memudahkan analisis maupun penentuan terhadap lokasi-lokasi rawan kecelakaan berdasarkan prediksi dan estimasi dari pola kejadian yang sejenis. Untuk mewujudkan hal tersebut, maka metode jaringan syaraf tiruan merupakan salah satu metode yang tepat untuk melakukan analisis pencocokan pola (pattern matching) dari sejumlah database. Hasil analisis dari penelitian sebelumnya digunakan sebagai dasar kajian yang dilakukan pada paparan studi ini $[7,12,13]$. 


\section{TINJAUAN PUSTAKA}

\subsection{Daerah Rawan Kecelakaan}

Daerah rawan kecelakaan adalah daerah yang mempunyai angka kecelakaan tinggi, resiko dan potensi kecelakaan yang tinggi pada suatu ruas jalan [11]. Dalam Pedoman Penanganan Lokasi Rawan Kecelakaan Lalu Lintas Departemen Permukiman dan Prasarana Wilayah, dinyatakan bahwa suatu lokasi dapat dinyatakan sebagai lokasi rawan kecelakaan apabila [2]:

a. Memiliki angka kecelakaan yang tinggi

b. Lokasi kejadian kecelakaan relatif bertumpuk.

c. Lokasi kecelakaan berupa persimpangan, atau segmen ruas jalan sepanjang 100-300m untuk jalan perkotaan, atau segmen ruas jalan sepanjang $1 \mathrm{~km}$ untuk jalan antar kota

d. Kecelakaan terjadi dalam ruang dan rentang waktu yang relatif sama

e. Memiliki penyebab kecelakaan dengan faktor yang spesifik

\subsection{Artificial Neural Network}

Artificial Neural Network (ANN) atau yang biasa disebut dengan Jaringan Saraf Tiruan (JST) merupakan salah satu upaya manusia untuk memodelkan cara kerja dari sistem syaraf manusia untuk melakukan suatu tugas tertentu dalam sistem teknik komputasi. $[12,13]$. Jaringan syaraf tiruan adalah suatu jaringan dari sekelompok pemroses kecil yang dimodelkan berdasarkan jaringan saraf manusia. JST merupakan sistem adaptif yang dapat merubah strukturnya untuk memecahkan masalah berdasarkan informasi eksternal maupun internal yang mengalir melalui jaringan tersebut. Jaringan syaraf tiruan mampu melakukan pengenalan kegiatan berbasis data masa lalu. Data masa lalu akan dipelajari oleh jaringan syaraf tiruan sehingga mempunyai kemampuan untuk memberikan keputusan terhadap data yang belum pernah dipelajari. Secara prinsip jaringan syaraf tiruan dapat melakukan komputasi terhadap semua fungsi yang dapat terhitung (computable function). Dalam prakteknya, JST sangat berguna untuk mengklasifikasi permasalahan yang dapat mentolerir ketidakpastian, yang memiliki banyak data, namun memiliki aturan-aturan yang tidak dapat diaplikasikan secara mudah. Prinsip dalam proses jaringan syaraf tiruan seperti tercantum pada Gambar 2.

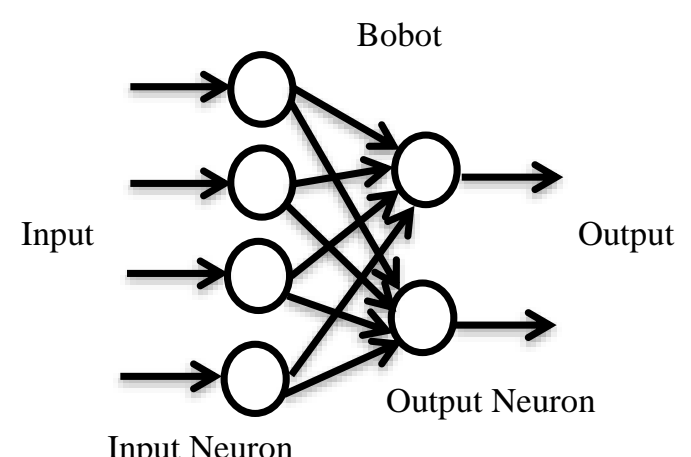

Gambar 2. Pola jaringan syaraf tiruan

Terdapat dua tipe algoritma dalam jaringan syaraf tiruan, yaitu: (1) supervised learning (terdiri atas beberapa tipe pembelajaran: hebb rule, perceptron, delta rule dan backpropagation); dan (2) unsupervised learning. Dari kedua metode tersebut yang paling umum digunakan adalah supervised learning back propagation, sehingga pada kajian menggunakan metode ini untuk proses analisis. Sistem arsitektur pada jaringan neural network backpropagation seperti tercantum pada gambar $3[10,12]$.

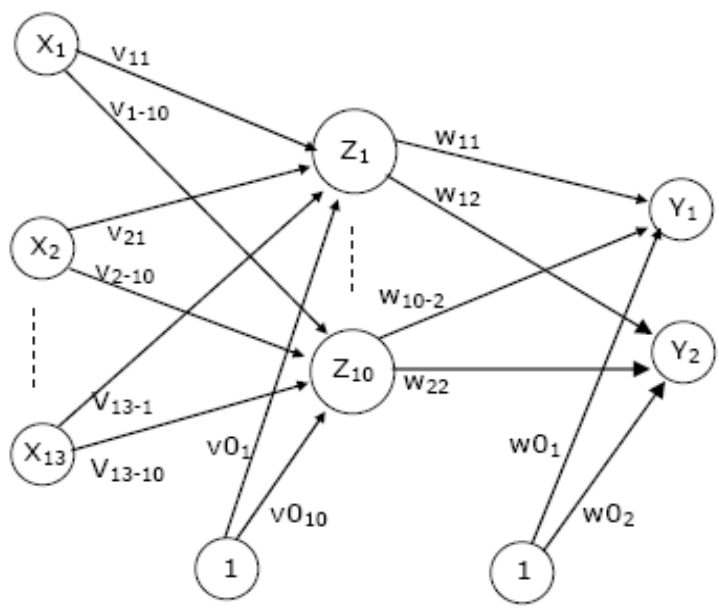

Gambar 3. Jaringan backpropagation

\section{METODE PENELITIAN}

Dalam penelitian ini, kajian dilakukan pada 11 ruas jalan yang ada di wilayah Kabupaten Malang, yaitu:

(1) Jaringan jalan Karanglo-Lawang;

(2) Jaringan jalan Bululawang-Turen;

(3) Jaringan jalan Kepanjen-Pagak;

(4) Kepanjen-Ampelgading;

(5) Jaringan jalan Gadang-Penarukan;

(6) Jaringan jalan Bululawang-Gondanglegi;

(7) Jaringan jalan Bululawang-Wajak; 
(8) Jaringan jalan Turen-Kepanjen;

(9) Jaringan jalan Malang-Kasembon;

(10) Jaringan jalan Kepanjen-Karangkates;

(11) Jaringan jalan Pakis-Tumpang.

Pengumpulan data primer diperoleh dari

hasil pengukuran dan pengamatan terhadap

kondisi lalu lintas, kondisi jalan dan kondisi lingkungan jalan dari ruas jalan yang menjadi obyek studi, ditunjang dengan data sekunder yang berasal dari Satlantas Polres Kabupaten Malang.

Variabel yang digunakan pada penelitian ini diperoleh dari hasil kajian penelitian terdahulu. Variabel pada penelitian ini adalah jumlah jalur, panjang jalan, lebar jalan, volume kendaraan, kecepatan kendaraan dan kondisi geometrik jalan) dan penyebab kejadian kecelakaan (manusia, kendaraan, kondisi jalan, fasilitas pendukung jalan dan kondisi lingkungan jalan).

Tahapan studi diawali dengan pengumpulan data penelitian dan skoring sesuai dengan variabel penelitian yang ditetapkan. Selanjutnya dilakukan pemetaan database jalan yang telah dikumpulkan dengan berbasis pada neural network backpropagation menggunakan toolbox Matlab. Hasil skoring pada variabel penelitian akan menjadi input dalam proses learning pada neural network. Berdasarkan hasil kajian penelitian terdahulu telah teridentifikasi daerah-daerah rawan kecelakaan dari sebelas rute yang dianalisis sehingga data ini digunakan sebagai dasar penetapan output yaitu daerah yang teridentifikasi sebagai lokasi rawan kecelakaan. Sejumlah sepuluh ruas jalan menjadi data training pada pendekatan analisis, sementara satu data sisanya akan digunakan sebagai data untuk validasi hasil pendekatan analisis. Bagan alir studi tercantum secara lengkap pada Gambar 4.

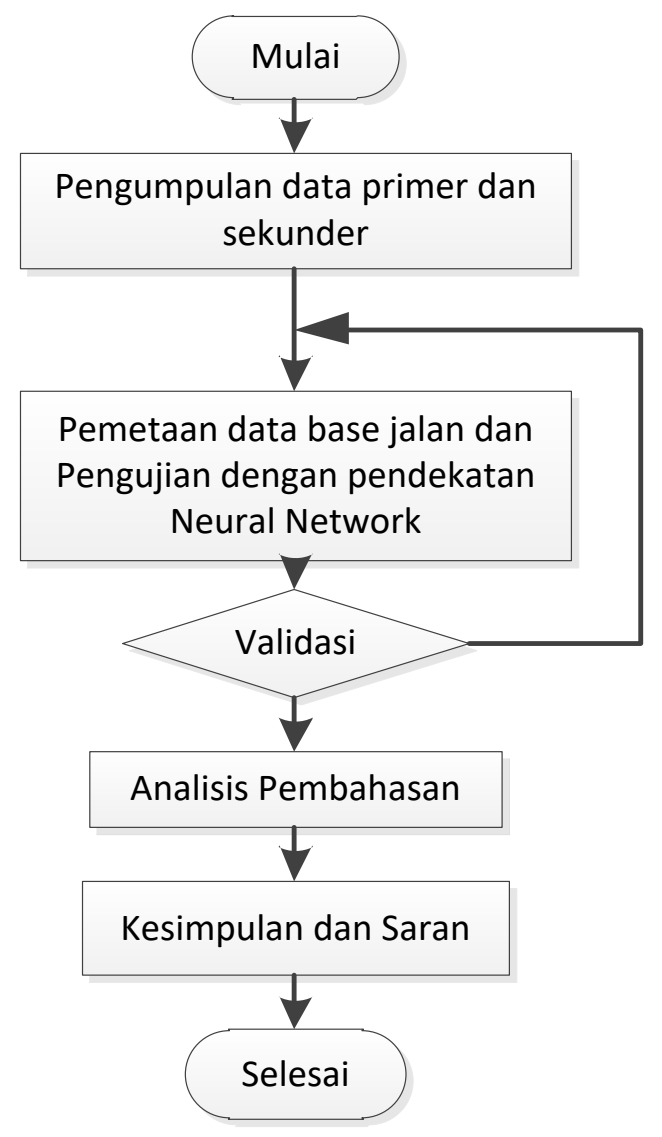

Gambar 4. Bagan alir studi

\section{HASIL DAN PEMBAHASAN}

Tahap awal dalam analisis adalah melakukan skoring pada variabel penelitian, dimana tujuan dari pemberian skor adalah memudahkan proses learning pada pemetaan data dengan pendekatan neural network. Hasil skoring dicantumkan dalam Tabel 1.

Tabel 1. Hasil skoring variabel penelitian

\begin{tabular}{cccccccccccc}
\hline \multirow{2}{*}{$\begin{array}{c}\text { Ruas } \\
\text { Jalan }\end{array}$} & $\begin{array}{c}\text { Panjang } \\
\text { Jalan }\end{array}$ & $\begin{array}{c}\text { Lebar } \\
\text { Jalan }\end{array}$ & Jumlah & Jalur & Vol. & Kecep. & Kond. Geom. & \multicolumn{5}{c}{ Penyebab Kecelakaan } \\
\cline { 10 - 13 } & & Kend. & Jalan & Human & Kend. & Jalan & Fas & Lingk \\
\hline 1 & 1 & 2 & 1 & 2 & 3 & 1 & 4 & 1 & 1 & 1 & 1 \\
\hline 2 & 1 & 1 & 1 & 2 & 3 & 2 & 2 & 3 & 2 & 1 & 1 \\
\hline 3 & 1 & 1 & 1 & 1 & 2 & 2 & 1 & 2 & 2 & 1 & 1 \\
\hline 4 & 3 & 1 & 1 & 1 & 3 & 2 & 1 & 3 & 2 & 1 & 1 \\
\hline 5 & 1 & 1 & 1 & 2 & 2 & 2 & 2 & 2 & 2 & 1 & 1 \\
\hline 6 & 1 & 1 & 1 & 1 & 3 & 2 & 1 & 3 & 2 & 1 & 1 \\
\hline 7 & 1 & 1 & 1 & 1 & 2 & 2 & 1 & 2 & 2 & 1 & 1 \\
\hline 8 & 4 & 1 & 1 & 1 & 3 & 1 & 1 & 3 & 1 & 1 & 1 \\
\hline 9 & 1 & 1 & 1 & 2 & 4 & 2 & 2 & 4 & 2 & 1 & 1 \\
\hline 10 & 1 & 1 & 1 & 2 & 2 & 2 & 2 & 2 & 2 & 1 & 1 \\
\hline
\end{tabular}


Untuk variabel panjang jalan, kategori skoring dibagi menjadi 4 yaitu: $0-15 \mathrm{~km}=$ skor $1,16-30 \mathrm{~km}=$ skor $2,31-45 \mathrm{~km}=$ skor 3 dan $46-60 \mathrm{~km}=$ skor 4 , sedangkan untuk variabel lebar jalan, dibagi menjadi 7, yaitu: $6.1-7.0 \mathrm{~m}=$ skor $1 ; 7.1-8.0 \mathrm{~m}=$ skor $2 ; 8.1-9.0 \mathrm{~m}=$ skor 3 ; $9.1-10.0 \mathrm{~m}=$ skor $4 ; 10.1-11 \mathrm{~m}=$ skor 5 ; $11.1-12 \mathrm{~m}=$ skor $6 ; 12.1-13 \mathrm{~m}=$ skor 7 . Sementara untuk variabel jumlah jalur dibagi menjadi 2 yaitu: $4 / 2=$ skor 2 dan $2 / 2=$ skor 1 .

Data volume kendaraan dalam satuan kend/hari dibagi ke dalam 4 kategori yaitu: 10.1-30 = skor $1 ; 30.1-50=$ skor $2 ; 50.1-70=$ skor 3 ; 70.1-90 = skor 4 , sedangkan variabel kecepatan kendaraan $(\mathrm{km} / \mathrm{jam})$ juga dibagi menjadi 4 rentang penilaian yaitu: $40.1-50=$ skor 1 ; $50.1-60=$ skor $2 ; 60.1-70=$ skor $3 ; 70.1-80=$ skor 4, dan data geometric jalan dibagi menjadi 2 yaitu appropriate $=$ skor 2 dan less $=$ skor 1.

Faktor-faktor yang menjadi penyebab kecelakaan terdiri atas manusia, kendaraan, jalan, fasilitas kelengkapan jalan dan lingkungan jalan, dibagi menurut kategori jumlah kejadiannya yaitu dengan rentang skoring: $0-15=$ skor $1 ; 16-30=$ skor $2 ; 31-45=$ skor $3 ; 46-60=$ skor 4 .

Faktor-faktor diatas adalah faktor yang menjadi input dalam analisis pendekatan menggunakan neural network, sehingga diperlukan target output dari pendekatan yang dilakukan, dimana pada studi ini yang menjadi output adalah identifikasi daerah rawan kecelakaan. Data daerah rawan kecelakaan diperoleh dari hasil studi sebelumnya [7] (Ma'ruf, Sulistio, \& Anwar, 2016). Seperti pada data input, data output juga harus dirubah ke dalam bentuk skoring untuk memudahkan analisis, sehingga kategori daerah rawan kecelakaan dibai menjadi 2 yaitu rawan $=$ skor 2 , tidak rawan $=$ skor 1 .

Hasil klasifikasi data input dan output selanjutnya dijadikan sebagai inisiasi awal untuk input pada toolbox matlab. Data ini yang digunakan oleh program untuk melakukan learning atau pemetaan. Gambar 5 dan Gambar 6 menunjukkan entry data ke dalam toolbox matlab yaitu data input dan data output.

Kemudian ditetapkan parameter training yaitu memastikan input dan target data telah benar terisi, memastikan tipe jaringan yang digunakan back propagation, dan pada studi ini digunakan dua layer karena jumlah layer menentukan akurasi ouput namun jumlah database relatif sedikit (10 data) sehingga tidak memerlukan banyak layer. Selanjutnya dilakukan training data yang telah diisikan (Gambar 7).

Hasil akhir aplikasi pada Gambar 8 menunjukkan bahwa proses training data dengan pendekatan neural network telah berhasil dilakukan sesuai dengan data-data entry-an dari karakteristik masing-masing ruas jalan di Kabupaten Malang untuk mendapatkan identifikasi daerah rawan kecelakaan jalan mengacu pada pola sejenis yang telah dipetakan dalam training program.

Tahap selanjutnya adalah pengujian hasil training data dengan menggunakan sisa data karakteristik ruas jalan sebagai sampel data training. Ruas jalan yang digunakan memiliki skor untuk masing-masing karakteristik sebagai berikut: panjang jalan $=$ skor 1 , lebar jalan $=$ skor 7, jumlah jalur $=$ skor 2 , volume kendaraan $=$ skor 4, kecepatan kendaraan $=$ skor 4, kondisi geometrik jalan $=$ skor 2 , faktor penyebab kecelakaan akibat manusia $=$ skor 4 , kendaraan $=$ skor 1 , jalan $=$ skor 1 , fasilitas kelengkapan jalan $=$ skor 2 , dan lingkungan $=$ skor 1 . Hasil analisis studi sebelumnya menunjukkan bahwa pada ruas jalan yang digunakan untuk pengujian teridentifikasi sebagai daerah rawan kecelakaan sehingga diberikan penilaian skoring $=2$. Hasil analisis terdahulu ini yang digunakan sebagai pembanding dengan output program, setelah input data training dijalankan. Hasil pengujian seperti tertera pada Gambar 9.

Output aplikasi menggunakan data salah satu ruas jalan di wilayah Kabupaten Malang menghasilkan nilai skoring 1.9997 (Gambar 9), sementara menurut hasil penelitian sebelumnya ruas jalan tersebut teridentifikasi sebagai daerah rawan kecelakaan dan bernilai skoring 2.000, sehingga hasil pengujian menunjukkan kesesuaian antara pendekatan berbasis faktor penyebab kecelakaan dan analisis berbasis data kecelakaan dengan selisih nilai sebesar $0.015 \%$.

Hasil pengujian dan selisih nilai pendekatan menunjukkan bahwa pendekatan identifikasi daerah rawan kecelakaan dengan menggunakan data-data faktor penyebab kecelakaan dapat digunakan sebagai salah satu solusi dalam penetapan keputusan daerah rawan kecelakaan sebagai upaya pencegahan kejadian kecelakaan dan untuk peningkatan keselamatan jalan. 


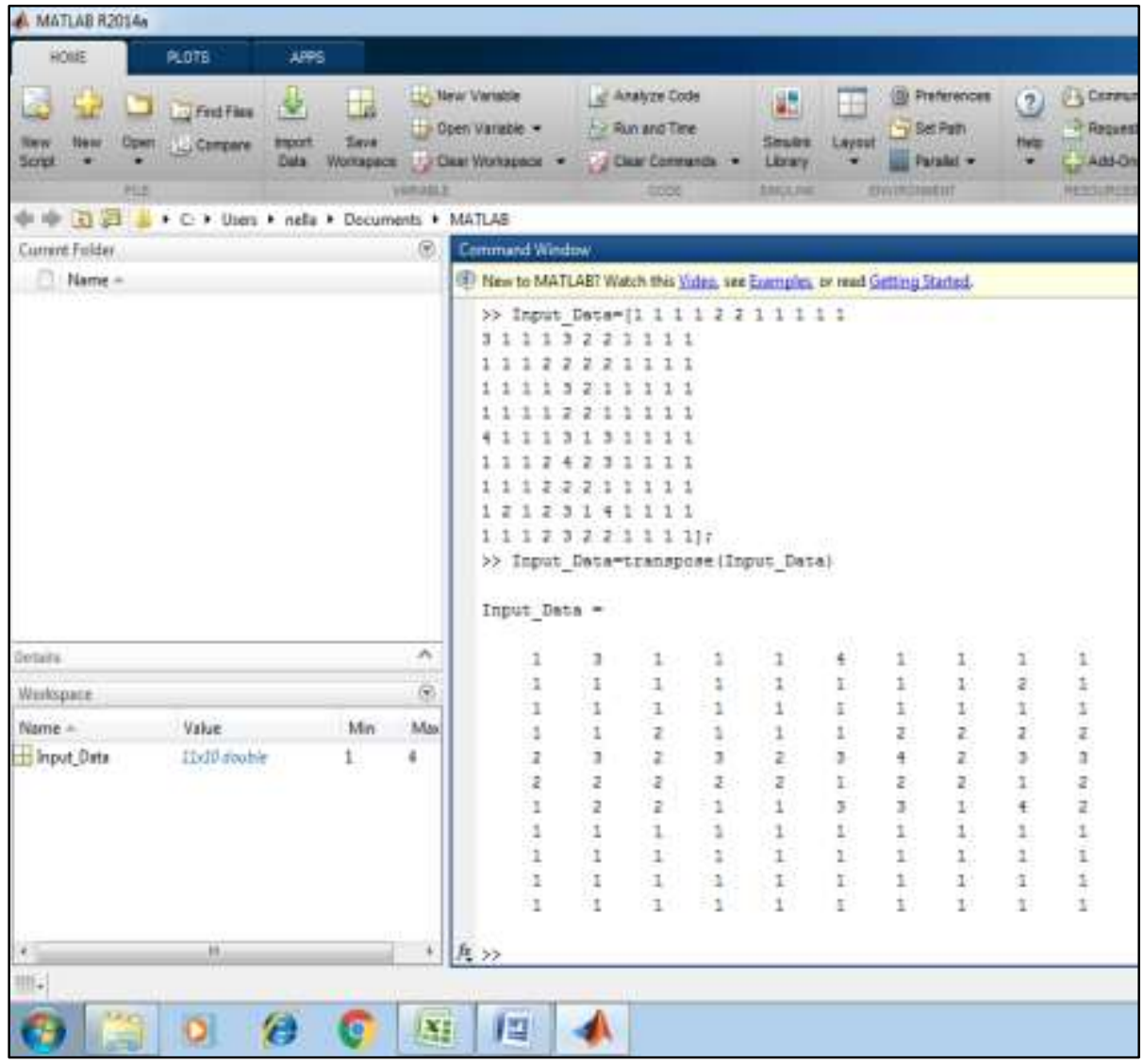

Gambar 5. Entry data input

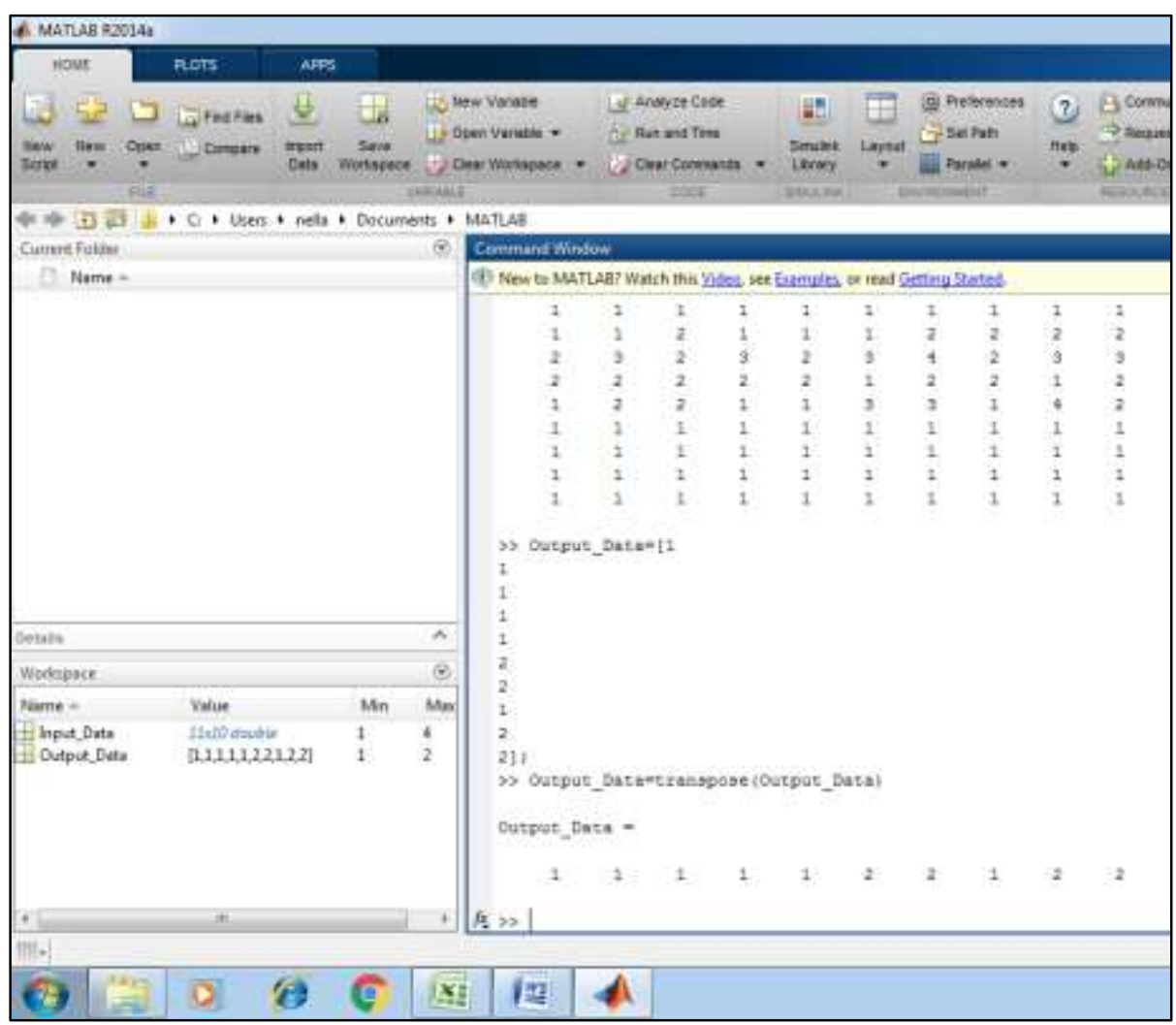

Gambar 6. Entry data output 


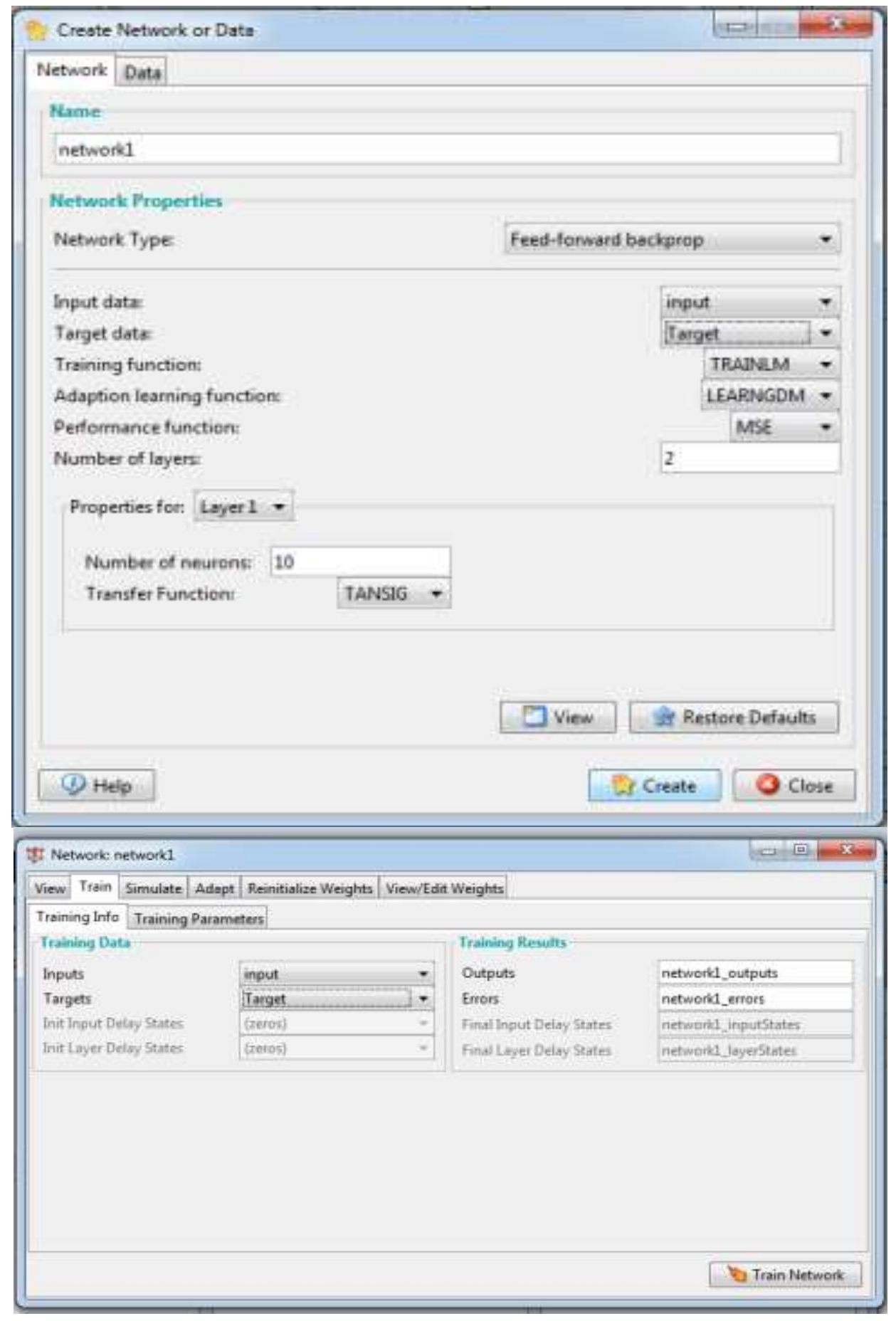

Gambar 7. Parameter training dalam NN 


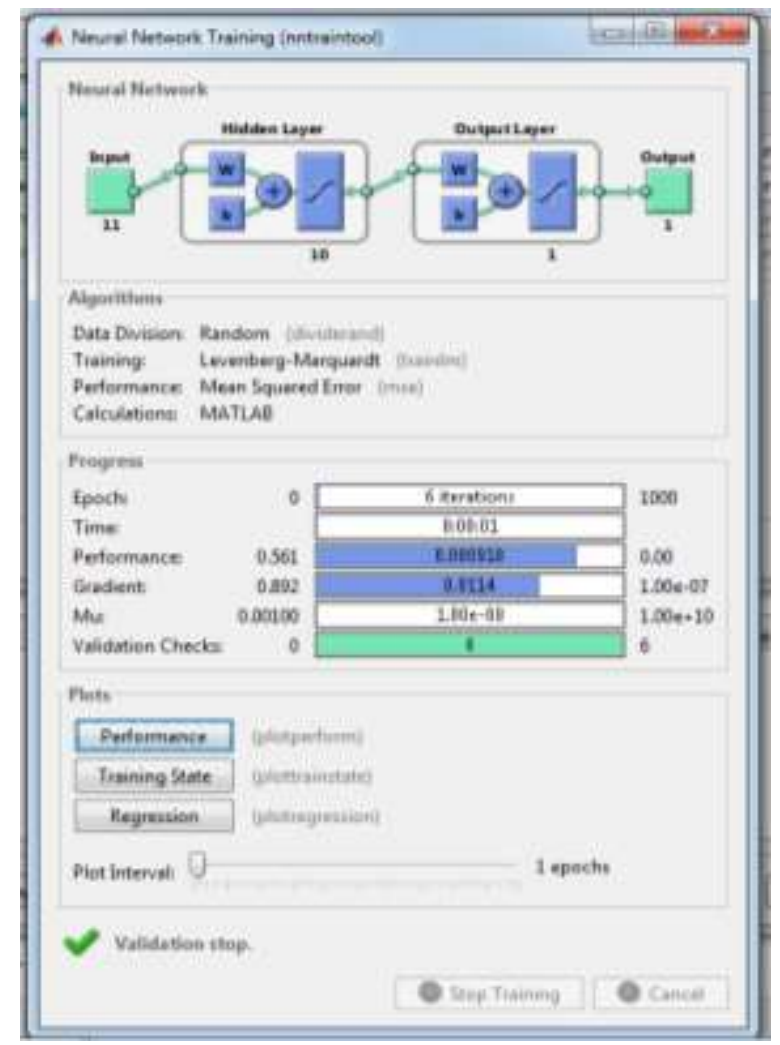

Gambar 8. Hasil training data

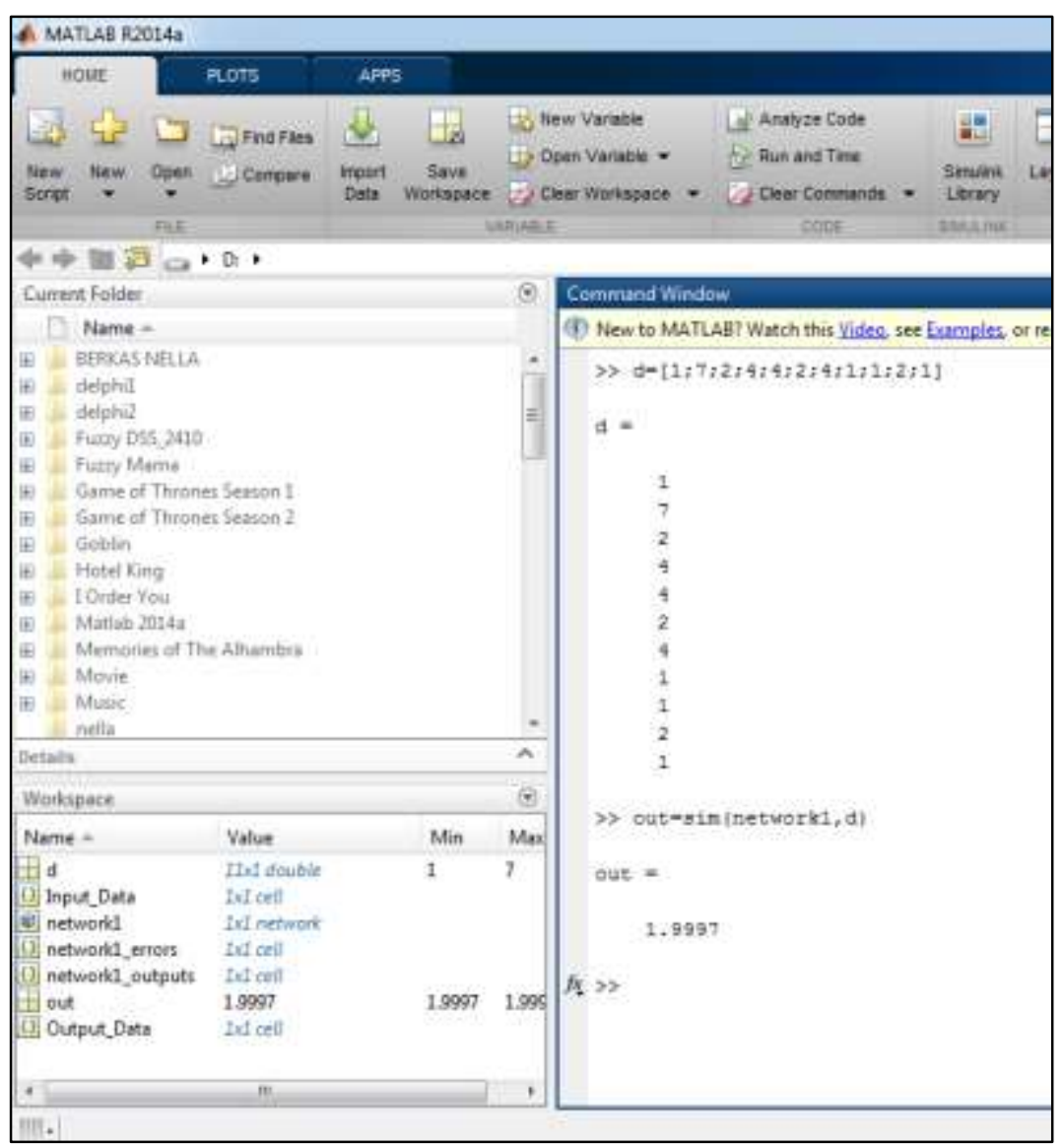

Gambar 9. Hasil pengujian dengan data sampel 


\section{KESIMPULAN DAN SARAN 5.1 Kesimpulan}

Hasil training pendekatan neural network menggunakan data dari ruas-ruas jalan di Kabupaten Malang dapat mengidentifikasi daerah rawan kecelakaan jalan sehingga dapat dijadikan salah satu solusi pencegahan kecelakaan lalu lintas.

Hasil pengujian dengan menggunakan data salah satu ruas jalan di wilayah Kabupaten Malang menunjukkan kesesuaian hasil pendekatan berbasis faktor penyebab kecelakaan dan hasil analisa berbasis data kecelakaan dengan selisih nilai sebesar $0.015 \%$.

\subsection{Saran}

Semakin banyak database yang terkumpul dan menjadi data input, maka akurasi pendekatan neural network akan semakin presisi dalam mengidentifikasi daerah rawan kecelakaan. Area studi dapat diperluas untuk wilayah studi yang lebih luas misalkan wilayah Malang Raya atau Jawa Timur sehingga dapat memberikan manfaat yang lebih besar dalam pencegahan kejadian kecelakaan lalu lintas.

\section{DAFTAR PUSTAKA}

[1] ---, Audit Keselamatan Jalan, Pedoman Konstruksi dan Bangunan Pd T-17-2005 B, 2005, Jakarta: Departemen Pekerjaan Umum Republik Indonesia

[2] ---, Penanganan Lokasi Rawan Kecelakaan Lalu Lintas Pedoman Konstruksi dan Bangunan, Pd T-09-2004-B, 2004, Jakarta: Departemen Permukiman dan Prasarana Wilayah Republik Indonesia

[3] Enggarsari, U., dan Sa'diyah, N. K., Kajian Terhadap Faktor-Faktor Penyebab Kecelakaan Lalu Lintas Dalam Upaya Perbaikan Pencegahan Kecelkaan Lalu Lintas, 2017, Perspektif Volume 22 No. 3, 228-237

[4] Hidayati, A., dan Hendrati, L. Y., Analisis
Risiko Kecelakaan Lalu Lintas Berdasar Pengetahuan, Penggunaan Jalur dan Kecepatan Berkendara, 2016, Jurnal Berkala Epidermiologi Vol 4. No. 2, 275-287

[5] Keymanesh, M., Ziari, H., Roudini, S., dan Ahangar, A. N., Identification and Prioritization of "Black Spot" Without Using Accident Information, 2017, Modelling and Simulation In Engineering, 1-9

[6] Marsaid, Hidayat, M., dan Ahsan, Faktor Yang Berhubungan Dengan Kejadian Kecelakaan Lalu Lintas Pada Pengendara Sepeda Motor Di Wilayah Polres Kabupaten Malang, 2013, Jurnal Ilmu Keperawatan Volume 1, No. 2, 98-112

[7] Ma'ruf, A., Sulistio, H., dan Anwar, M. R., Kajian Audit Keselamatan Jalan Pada Sebelas Ruas Jalan Utama Di Wilayah Kabupaten Malang, 2016, Tesis, Universitas Brawijaya Malang

[8] Ma'ruf, A., Sulistio, H., dan Anwar, M. R., Kajian Audit Keselamatan Jalan Pada Sebelas Ruas Jalan Utama Di Wilayah Kabupaten Malang, 2016, Prokons Jurnal Teknik Sipil Vol. 10 No. 2, 69-78

[9] Mulyono, A. T., Kushari, B., dan Gunawan, H. E., 2009, Audit Keselamatan Infrastruktur Jalan (Studi Kasus Jalan Nasional KM 78-KM 79 Jalur Pantura Jawa, Kabupaten Batang), 2009, Jurnal Teknik Sipil-Jurnal Teoritis dan Terapan Bidang Rekayasa Sipil Vo.16 No. 3, 163-174

[10] Purnomo, M. H., Supervised Neural Network Dan Aplikasinya, 2006, Jakarta: Graha Ilmu.

[11] Putri, C. E., Analisis Karakteristik Kecelakaan Dan Faktor Penyebab Kecelakaan Pada Lokasi Blackspot Di Kota Kayu Agung, 2014, Jurnal Teknik Sipil dan Lingkungan Vol. 2 No. $1,154-161$

[12] Suyanto, Artificial Intelligence Searching, Reasoning, Planning, Learning, 2014, Bandung: Informatika

[13] Widodo, P. P., dan Handayanto, R. T., Penerapan Soft Computing Dengan MATLAB, 2012, Bandung: Rekayasa Sains 